\title{
Evidence for a Regulatory Element Controlling Amino Acid Transport System L in Chinese Hamster Ovary Cells
}

\author{
Ellen J. Collarini, George S. Campbell, and Dale L. Oxender \\ Department of Biological Chemistry, University of Michigan, Ann Arbor, Michigan 48109
}

\begin{abstract}
We have used the technique of somatic cell hybridization to study the regulation of the neutral amino acid transport system $\mathrm{L}$ in Chinese hamster ovary $(\mathrm{CHO})$ cells. The cell line $\mathrm{CHO}-t s 025 \mathrm{C} 1$ has a temperature-sensitive mutation in leucyl-tRNA synthetase. At the nonpermissive temperature of $39^{\circ} \mathrm{C}, \mathrm{CHO}-t s 025 \mathrm{C} 1$ cells are unable to charge leucyl-tRNA and behave as though starved for leucine by increasing their system $L$ transport activity two- to fourfold. From the temperature-sensitive cell line, we have isolated a regulatory mutant cell line, $\mathrm{CHO}-\mathrm{C} 11 \mathrm{~B} 6$, that has constitutively elevated system $\mathrm{L}$ transport activity. The $\mathrm{CHO}-\mathrm{C} 11 \mathrm{~B} 6$ cell line retains the temperature-sensitive leucyl-tRNA synthetase mutation, but growth of this cell line is temperature resistant because its increased system $L$ transport activity leads to increased intracellular leucine levels, which compensate for the defective synthetase. Hybrid cells formed by fusion of the temperature-sensitive $\mathrm{CHO}-t \mathrm{~s} 025 \mathrm{C} 1$ cells and the temperature-resistant $\mathrm{CHO}-\mathrm{C} 11 \mathrm{~B} 6$ cells show temperature-sensitive growth and temperature-dependent regulation of leucine transport activity. These data suggest that the system $\mathrm{L}$ activity of $\mathrm{CHO}$ cells is regulated by a dominant-acting element that is defective or absent in the regulatory mutant CHO-C11B6 cell line. 1994 Wiley-Liss, Inc.
\end{abstract}

Key words: amino acid transport, transport regulation, transport system L, CHO cells, hybrid cells

The mammalian cell neutral amino acid transport system $\mathrm{L}$ is $\mathrm{Na}^{+}$-independent and transports mainly branched-chain and aromatic amino acids [Collarini and Oxender, 1987]. System L activity is regulated by amino acid availability in Chinese hamster ovary (CHO) cells. Severe starvation of CHO-K1 cells for leucine causes system L transport activity to increase three- to fourfold [Moreno et al., 1985]. Regulation of system L can also be observed in the CHO cell lines $\mathrm{CHO}-t s \mathrm{H} 1$ and $\mathrm{CHO}-t s 025 \mathrm{C} 1$, two temperature-sensitive leucyl-tRNA synthetase mutants [Thompson et al., 1973; Giles et al., 1980]. At the nonpermissive temperature of $39^{\circ} \mathrm{C}$, these cells are unable to charge leucyl-tRNA and behave as though starved for leucine, and system

Received January 17, 1994; accepted April 29, 1994.

George S. Campbell's present address is Department of Physiology, University of Michigan, Ann Arbor, MI 48109.

Dale L. Oxender's present address is Biotechnology Department, Parke-Davis Pharmaceutical Research Division, Warner-Lambert Company, 2800 Plymouth Road, Ann Arbor, MI 48105.

Address reprint requests to Dr. Ellen J. Collarini (present address), Laboratory for Molecular Cell Biology, Gower Street, University College, London WC1E 6BT, England.
$\mathrm{L}$ transport activity increases two- to fourfold [Moore et al., 1977; Shotwell et al., 1982; Lobaton et al., 1984]. The temperature-dependent enhancement of transport activity in these cell lines is specific to system $L$ and is accompanied primarily by an increase in the $V_{\max }$ value of $\mathrm{Na}^{+}$-independent leucine uptake [Shotwell et al., 1982; Lobaton et al., 1984].

We have isolated temperature-resistant cell lines from mutagen-treated $\mathrm{CHO}-t s \mathrm{H} 1$ cells by selecting for survival at $39^{\circ} \mathrm{C}$ and low leucine concentrations [Shotwell et al., 1983]. The temperature-resistant cell lines show increased and unregulated system L transport activity compared to the parental cell line, with no changes in the other neutral amino acid transport systems [Shotwell et al., 1983]. These cell lines still retain the temperature-sensitive leucyl-tRNA synthetase [Shotwell et al., 1983]. The temperature resistance of these cell lines appears to be the result of increased and unregulated system $\mathrm{L}$ transport activity, which leads to increased intracellular leucine levels. The increased intracellular levels of leucine in the regulatory mutant cell lines compensate for the defective leucyltRNA synthetase in essentially the same way

1994 Wiley-Liss, Inc. 
that higher levels of leucine in the media permit growth of the parental CHO-ts $\mathrm{H} 1$ cell line at nonpermissive temperatures [Mulnar and Rauth, 1975, 1979; Farber and Deutscher, 1976]. These results suggest that the temperatureresistant regulatory transport mutants may be defective in an element that is necessary for system $L$ regulation [Shotwell et al., 1983].

To further investigate the mechanism of system $\mathrm{L}$ regulation, we used the technique of somatic cell hybridization to form $\mathrm{CHO}$ cell hybrids between the regulatory mutant cell line CHO-C11B6 and the CHO-ts025C1 cell line, the only difference between these two cell lines being the alteration in system $\mathrm{L}$ regulation [Shotwell et al., 1983; Lobaton et al., 1984]. This paper presents evidence that system $\mathrm{L}$ activity may be controlled by a dominant regulatory element.

\section{MATERIALS AND METHODS Cell Lines and Culture Methods}

The temperature-sensitive leucyl-tRNA synthetase mutant cell line $\mathrm{CHO}-t s 025 \mathrm{C} 1$ was obtained from R.E. Giles. This cell line is defective in the enzyme hypoxanthine phosphoribosyltransferase (HPRT ${ }^{-}$) [Giles et al., 1980]. These cells were transfected with the cosmid vector pCV108, which carries the gene coding for resistance to the antibiotic G418 [Lau and Kan, 1983]. The transfected subclone of the CHO$t s 025 \mathrm{C} 1$ cell line used in these studies, referred to as CHO-R100 [El-Gewely and Oxender, 1985], was maintained at $34^{\circ} \mathrm{C}$ in Eagle's minimal essential medium (MEM) (KC Biological, Lenexa, $\mathrm{KS}$ ), containing Earle's salts and nonessential amino acids, supplemented with $5 \%(\mathrm{v} / \mathrm{v})$ fetal calf serum (FCS) (KC Biological), $2.2 \mathrm{~g} / \mathrm{L}$ sodium bicarbonate, and $200 \mu \mathrm{g} / \mathrm{ml} \mathrm{G418}$ (GIBCO, Grand Island, NY). The cell line CHO-C11B6 was isolated from mutagen-treated $\mathrm{CHO}-t s \mathrm{H} 1$ cells in our laboratory [Shotwell et al., 1983]. This cell line was maintained at $39^{\circ} \mathrm{C}$ in leucinefree MEM containing Earle's salts and nonessential amino acids, supplemented with $5 \%(\mathrm{v} / \mathrm{v})$ dialyzed FCS, $2.2 \mathrm{~g} / \mathrm{L}$ sodium bicarbonate, and L-leucine to a final concentration of $0.1 \mathrm{mM}$. All cultures were maintained at $\mathrm{pH} 7.4$ in a humidified incubator equilibrated to a $5 \% \mathrm{CO}_{2}$ atmosphere. Cells were harvested using a $0.01 \%$ trypsin solution in Dulbecco's phosphate-buffered

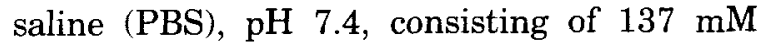
$\mathrm{NaCl}, 2.7 \mathrm{mM} \mathrm{KCl}, 10.6 \mathrm{mM} \mathrm{Na}_{2} \mathrm{HPO}_{4}$, and 1.5 $\mathrm{mM} \mathrm{KH} \mathrm{KO}_{4}$. For transport assays, a sodium- free buffer, $\mathrm{pH} 7.4$, was used in which equimolar amounts of choline chloride and choline phosphate replaced the $\mathrm{NaCl}$ and the sodium phosphate, respectively. This buffer is referred to as PBC and was prepared as described previously [Shotwell et al., 1981]. A modification of PBC, with $5.6 \mathrm{mM}$ D-glucose, $0.5 \mathrm{mM} \mathrm{MgCl}_{2}$, and 0.9 $\mathrm{mM} \mathrm{CaCl}, \mathrm{pH} 7.4$, was referred to as PBCGMC.

\section{Hybridizations}

Hybridizations were carried out using established procedures [Adair et al., 1978; Klebe and Mancuso, 1981]; 4-5 $\times 10^{5}$ cells of each cell line were plated together in one well of a 24 -well dish (Costar) and incubated overnight at $34^{\circ} \mathrm{C}$ in MEM with 5\% FCS. The next day, the cells were washed with $2 \mathrm{ml}$ minimal attachment medium (MAM), containing $116 \mathrm{mM} \mathrm{NaCl}, 5.4 \mathrm{mM} \mathrm{KCl}$, $5.5 \mathrm{mM}$ D-glucose, and $10 \mathrm{mM}$ HEPES, $\mathrm{pH} 7.55$. The medium was removed, and $200 \mu \mathrm{l}$ of $50 \%$ $(\mathrm{v} / \mathrm{v})$ polyethylene glycol (PEG-1000, Baker, Phillipsburg, NJ) in 0.15 M HEPES, $\mathrm{pH} 7.55$, was added to the cells for $1 \mathrm{~min}$ at room temperature. The cells were washed 3 times with $2 \mathrm{ml}$ MAM and incubated for $30 \mathrm{~min}$ at $34^{\circ} \mathrm{C}$ in $2 \mathrm{ml}$ MAM. The cells were then incubated overnight at $34^{\circ} \mathrm{C}$ in MEM with $5 \%$ FCS. The next day, the cells were trypsinized and plated in $100-\mathrm{mm}$ dishes (Corning) at a density of $5 \times 10^{4}$ cells/ dish in $10 \mathrm{ml}$ MEM with $5 \%$ FCS and incubated overnight at $34^{\circ} \mathrm{C}$. The next day, the medium was replaced with MEM containing $5 \%$ FCS, $500 \mu \mathrm{g} / \mathrm{ml} \mathrm{G} 418,100 \mu \mathrm{M}$ hypoxanthine, $0.4 \mu \mathrm{M}$ aminopterin, and $16 \mu \mathrm{M}$ thymidine (using HAT $\times 50$ supplement, Sigma). After 9 days at $34^{\circ} \mathrm{C}$, colonies were transferred and maintained in selective medium at $34^{\circ} \mathrm{C}$.

\section{Chromosome Counts}

Preparation of parental and hybrid cells for chromosome counts followed published procedures [Worton and Duff, 1979].

\section{Amino Acid Transport Assays}

The cluster tray assay was used for the transport assays [Gazzola et al., 1981]. Cells were plated at $1.4 \times 10^{5}$ (CHO-R100 and CHOC11B6 cell lines) or $0.7 \times 10^{4}$ (hybrid cell lines) in MEM with $5 \%$ FCS in a 24-well dish (Costar) and assayed after 16-20 h. The hybrids cells were larger and had higher protein values per cell than the parental cells, so they were plated 
at a lower density to ensure that all cell lines were at approximately the same level of confluence. The cells were washed with $2 \mathrm{ml} \mathrm{PBC}-$ GMC and incubated for $40 \mathrm{~min}$ at $34^{\circ} \mathrm{C}$ with a change of $\mathrm{PBC}-\mathrm{GMC}$ at $20 \mathrm{~min}$. We have established that this protocol completely eliminates any possible trans-effects [Collarini et al., 1989]. The $\mathrm{Na}^{+}$-independent uptake of $50 \mu \mathrm{M}$ leucine was then determined as previously described [Shotwell et al., 1981]. Cellular protein was determined using the method of Zak and Cohen [1961], as described previously [Shotwell et al., 1981]. The data were expressed as nanomoles leucine taken up per milligram protein per min.

\section{Kinetic Analysis}

Initial rates of uptake were determined for a series of leucine concentrations. Analyses of kinetic constants were carried out using a PASCAL program applying the Marquardt nonlinear leastsquares method to fit the parameters of the following equation:

$$
\mathrm{v}=\left(\mathrm{V}_{\max }[\mathrm{S}] / \mathrm{K}_{\mathrm{m}}+[\mathrm{S}]\right)+\mathrm{P}[\mathrm{S}] .
$$

In this equation, $\mathrm{v}, \mathrm{S}, \mathrm{V}_{\max }$, and $\mathrm{K}_{\mathrm{m}}$ have their usual meanings. $\mathrm{P}$ is the first-order term describing the nonsaturable uptake.

\section{Preparation of Double-Dialyzed Fetal Calf Serum}

Commercially available dialyzed FCS contains small but significant $(\sim 10 \mu \mathrm{M})$ amounts of leucine [Moreno et al., 1985]. Dialyzed FCS (KC Biological) was further dialyzed against $0.9 \%$ $\mathrm{NaCl}$ (1:20) for $72 \mathrm{~h}$ with two changes of the saline solution.

\section{Plating Efficiency}

Cells were plated at approximately 100 cells per $100-\mathrm{mm}$ dish in leucine-free MEM supplemented with $5 \%(\mathrm{v} / \mathrm{v})$ double-dialyzed FCS and $50 \mu \mathrm{M}$ leucine. The medium for the hybrid cell lines was also supplemented with HAT and 500 $\mu \mathrm{g} / \mathrm{ml} \mathrm{G} 418$. The cells were incubated at the indicated temperature for approximately 10 days, then fixed with $95 \%$ ethanol and stained with $0.1 \%$ crystal violet.

\section{Materials}

L- $\left[{ }^{3} \mathrm{H}\right]$ leucine (50-60 $\left.\mathrm{Ci} / \mathrm{mmol}\right)$ was obtained from ICN. L-leucine, trypsin, and crystal violet were purchased from Sigma.

\section{RESULTS \\ Hybridization}

CHO-ts025C1 cells, which are HPRT ${ }^{-}$, have been transfected with the cosmid vector $\mathrm{pCV} 108$, which carries the gene coding for resistance to the antibiotic G418 [Lau and Kan, 1983; ElGewely and Oxender, 1985]. The subclone of the G418-resistant CHO-ts025C1 cell line used in this study is referred to as CHO-R100 [ElGewely and Oxender, 1985]. The regulatory mutant cell line, CHO-C11B6, is both $\mathrm{HPRT}^{+}$and G418 sensitive, which permitted us to select hybrids between the $\mathrm{CHO}-\mathrm{R} 100$ and $\mathrm{CHO}-$ C11B6 cell lines. Hybrids were selected in medium containing hypoxanthine, aminopterin, thymidine (HAT supplement), and G418. The frequency of successfull fusion was approximately 1 in $10^{3}$ cells. Control fusions of either CHO-R100 $\times$ CHO-R100 cells and CHOC11B $6 \times$ CHO-C11B6 cells did not result in any surviving colonies in selective medium.

To be certain that the surviving colonies were hybrids, the number of chromosomes in the parental cells and the putative hybrid cells were determined. The average number of chromosomes in both the CHO-R100 and CHO-C11B6 cell lines was 20 . Four cell lines that were produced by the selection, designated $\mathrm{R} \times \mathrm{C} 1.5$, $1.6,2.1$, and 2.5, had average chromosome numbers of $40,39,35$, and 39 , respectively. The near-tetraploid chromosome number implied that these cell lines were hybrids. The hybrid cell lines were maintained in selective medium at $34^{\circ} \mathrm{C}$ for further analysis.

\section{Regulation of Leucine Transport Activity in the Hybrid Cell Lines}

Figure 1 shows the initial rate of $\mathrm{Na}^{+}$-independent leucine uptake by the CHO-R100, CHOC11B6, and hybrid cell lines, after a 9-h incubation at either $34^{\circ} \mathrm{C}$ or $39^{\circ} \mathrm{C}$. The CHO-R100 cell line showed temperature-dependent regulation of leucine uptake, while the CHO-C11B6 cell line showed elevated and unregulated transport activity. The hybrid cell lines all demonstrated temperature-dependent regulation of leucine uptake. For the hybrid cell lines, as well as for the CHO-R100 cell line, the rate of leucine uptake after incubation at $39^{\circ} \mathrm{C}$ was two- to threefold higher than that seen after incubation at $34^{\circ} \mathrm{C}$. The initial rates of leucine uptake in the hybrid cell lines were greatly reduced compared to the CHO-C11B6 cell line, although they were 


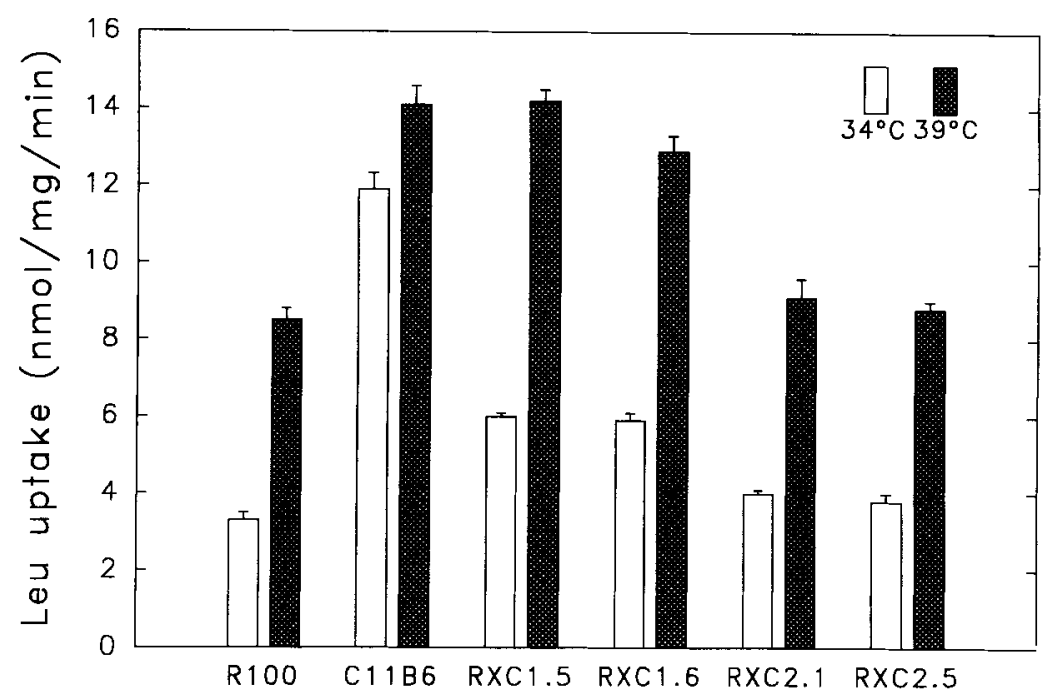

Fig. 1. Regulation of $\mathrm{Na}^{+}$-independent leucine uptake in the $\mathrm{CHO}-\mathrm{R} 100, \mathrm{CHO}-\mathrm{C} 11 \mathrm{~B} 6$, and $\mathrm{CHO}-\mathrm{R} 100 \times \mathrm{CHO}-\mathrm{C} 11 \mathrm{~B} 6$ hybrid cell lines. Cells were plated at either $1.4 \times 10^{5}$ cells $/$ well (the $\mathrm{CHO}-\mathrm{R} 100$ and $\mathrm{CHO}-\mathrm{C} 11 \mathrm{~B} 6$ cell lines), or at $7 \times 10^{4}$ cells/well (the hybrid cell lines) and grown in MEM at $34^{\circ} \mathrm{C}$.

slightly higher than that seen for the CHOR100 cell line.

\section{Time Course of Leucine Uptake in the Hybrid Cell Lines}

The time course of the $\mathrm{Na}^{+}$-independent uptake of $50 \mu \mathrm{M}$ leucine was measured in the CHO-R100, CHO-C11B6, and hybrid cell lines at $34^{\circ} \mathrm{C}$ (Fig. 2). The steady-state accumulation of leucine over $5 \mathrm{~min}$ by the hybrid cell lines was similar to that seen in the CHO-R100 cell line, indicating that the lower initial rate of leucine uptake at $34^{\circ} \mathrm{C}$ results in a lower steadyrate accumulation of leucine by the hybrid cell lines.

\section{Kinetics of Leucine Uptake by the CHO-R100, $\mathrm{CHO}-\mathrm{C11B6}$, and Hybrid Cell Lines}

We examined the kinetic parameters of $\mathrm{Na}^{+}$independent leucine uptake by the parental cell lines and the hybrid cell lines (Table I). The increased leucine uptake seen by the CHO$\mathrm{R} 100$ cell line at $39^{\circ} \mathrm{C}$ was accompanied by a twofold increase in the $\mathrm{V}_{\max }$ value after incubation at $39^{\circ} \mathrm{C}$ over that seen after incubation at $34^{\circ} \mathrm{C}$. The CHO-C11B6 cell line showed elevated $V_{\max }$ values at both temperatures, compared to CHO-R100, as reported previously [Shotwell et al., 1983]. Because the $K_{m}$ values for the $\mathrm{CHO}-\mathrm{C} 11 \mathrm{~B} 6$ cell line are also slightly higher that those for the $\mathrm{CHO}-\mathrm{R} 100$ cell line, the data are also expressed as the ratio $V_{\max } / K_{m}$,
One-half the dishes were then moved to $39^{\circ} \mathrm{C}$ and one-half left at $34^{\circ} \mathrm{C}$. After $9 \mathrm{~h}$, the $30-\mathrm{s} \mathrm{Na}{ }^{+}$-independent uptake of $50 \mu \mathrm{M}$ leucine was determined. Data are the averages of four determinations.

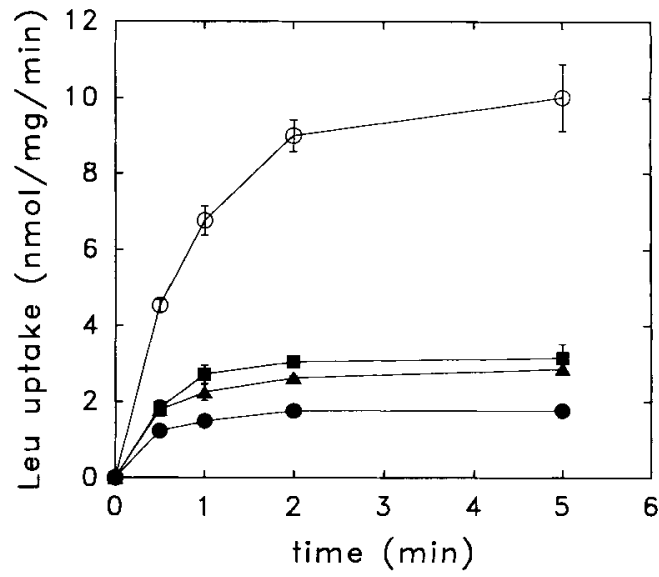

Fig. 2. Time course of $\mathrm{Na}^{+}$-independent leucine uptake at $34^{\circ} \mathrm{C}$ in the $\mathrm{CHO}-\mathrm{R} 100, \mathrm{CHO}-\mathrm{C} 11 \mathrm{~B} 6$, and $\mathrm{CHO}-\mathrm{R} 100 \times$ $\mathrm{CHO}-\mathrm{C} 11 \mathrm{~B} 6$ hybrid cell lines. Cells were plated at either $1.4 \times$ $10^{5}$ cells/well (the $\mathrm{CHO}-\mathrm{R} 100$ and $\mathrm{CHO}-\mathrm{C} 11 \mathrm{~B} 6$ cell lines) or $7 \times 10^{4}$ cells/well (the hybrid cell lines) and grown in MEM at $34^{\circ} \mathrm{C}$. The $\mathrm{Na}^{+}$-independent uptake of $50 \mu \mathrm{M}$ leucine was determined at the indicated times. Points are the averages of four determinations: $\mathrm{O}, \mathrm{CHO}-\mathrm{C} 11 \mathrm{~B} 6 ;-\mathrm{CHO}-\mathrm{R} 100 ; \mathbf{\square}, \mathrm{R} \times$ $\mathrm{C} 1.5 ; \mathbf{A}, \mathrm{R} \times \mathrm{C} 2.5$.

which is proportional to the actual rate of uptake at low substrate concentrations. These values show that the CHO-C11B6 cell line has a greatly increased rate of uptake over that seen for the CHO-R100 cell line. The hybrid cell lines $\mathrm{R} \times \mathrm{C} 1.5$ and $\mathrm{R} \times \mathrm{C} 2.5$ showed an increase in $\mathrm{V}_{\text {max }}$ values after incubation at $39^{\circ} \mathrm{C}$ over those seen after incubation at $34^{\circ} \mathrm{C}$, similar to the properties of the CHO-R100 cell line, although 
TABLE I. Kinetics of $\mathrm{Na}^{+}$-Independent Leucine Uptake by the CHO-R100, CHO-C11B6, and Hybrid Cell Lines*

\begin{tabular}{cccccc}
\hline & & & $\begin{array}{c}\mathrm{V}_{\max } \\
(\mathrm{nmol} / \\
\mathrm{mg} /\end{array}$ & $\begin{array}{c}P \\
(\mathrm{nmol} / \\
\mathrm{mg} / \mathrm{min} / \\
\mathrm{mM})\end{array}$ & $\begin{array}{c}\mathrm{V}_{\max } / \mathrm{K}_{\mathrm{m}} \\
(\mathrm{nmol} / \\
\mathrm{mg} / \mathrm{min} / \\
\mathrm{mM})\end{array}$ \\
\hline CHO- & 34 & 0.016 & 3.2 & 4.8 & 200 \\
R100 & 39 & 0.023 & 6.3 & 6.3 & 274 \\
CHO- & 34 & 0.038 & 14.7 & 5.5 & 387 \\
C11B6 & 39 & 0.058 & 18.9 & 4.0 & 326 \\
$\mathrm{R} \times \mathrm{C} 1.5$ & 34 & 0.021 & 6.1 & 7.1 & 290 \\
& 39 & 0.032 & 14.7 & 7.3 & 459 \\
$\mathrm{~K} \times \mathrm{C}$ 2.5 & 34 & 0.019 & 4.7 & 4.8 & 247 \\
& 39 & 0.023 & 8.0 & 5.2 & 348 \\
\hline
\end{tabular}

${ }^{*}$ Cells were depleted of internal amino acids at $34^{\circ} \mathrm{C}$. They were then plated and grown in MEM at $34^{\circ} \mathrm{C}$. After $8 \mathrm{~h}$ at $34^{\circ} \mathrm{C}$ or $39^{\circ} \mathrm{C}$, the cells were depleted of internal amino acids, and the 30-s uptake of leucine at concentrations of $5 \mu \mathrm{M}-2$ $\mathrm{mM}$ was determined in sodium-free buffer.

the hybrid cell lines had higher $\mathrm{V}_{\max }$ values than those of the CHO-R100 cell line at $34^{\circ} \mathrm{C}$. The $\mathrm{V}_{\max } / \mathrm{K}_{\mathrm{m}}$ values for the hybrid cell lines also show that these cell lines have a regulated phenotype similar to that of the CHO-R100 cell line.

\section{Plating Efficiency of the CHO-R100, CHO-C11B6, and Hybrid Cell Lines}

We examined whether the hybrid cell lines also demonstrated temperature-sensitive growth. The temperature sensitivity of the two hybrid cell lines was tested by comparing their plating efficiencies to those of the CHO-R100 and $\mathrm{CHO}-\mathrm{C} 11 \mathrm{~B} 6$ cell lines at $34^{\circ} \mathrm{C}$ and $39^{\circ} \mathrm{C}$ (Table II). CHO-R100 cells could only be plated successfully at $34^{\circ} \mathrm{C}$. CHO-C11B 6 cells plated equally well at both temperatures, in agreement with previous results [Shotwell et al., 1983]. The hybrid cells only plated well at $34^{\circ} \mathrm{C}$, indicating that they were temperature sensitive.

TABLE II. Plating Efficiency of the CHO-R100, CHO-C11B6, and CHO-R100 $\times$ CHO-C11B6 Hybrid Cell Lines*

\begin{tabular}{lrr}
\hline Cell line & $34^{\circ} \mathrm{C}$ & $39^{\circ} \mathrm{C}$ \\
\hline CHO-R100 & 87 & 0 \\
CHO-C11B6 & 114 & 124 \\
$\mathrm{R} \times \mathrm{C} 1.5$ & 69 & 0 \\
$\mathrm{R} \times \mathrm{C} 2.5$ & 78 & 4 \\
\hline
\end{tabular}

*Plating efficiency was determined as described under Materials and Methods. Numbers are the averages of two plates.

\section{DISCUSSION}

We have been using genetic approaches, as well as kinetic analyses, to examine amino acid transport system L activity and its regulation. The temperature-sensitive leucyl-tRNA synthetase mutant cells $\mathrm{CHO}-t s \mathrm{H} 1$ and $\mathrm{CHO}-t s 025 \mathrm{C} 1$ can be starved for leucine at elevated temperatures, and consequently increase their system L activity [Moore et al., 1977; Shotwell et al., 1982; Lobaton et al., 1984]. Mutants isolated from the $\mathrm{CHO}-t s \mathrm{H} 1$ cell line show increased and unregulated system $\mathrm{L}$ transport activity, suggesting that these cell lines are defective in a regulatory element that leads to constitutively elevated system L transport activity [Shotwell et al., 1983]. Fusion of the regulatory mutant cells with cells able to regulate system $\mathrm{L}$ produced hybrid cells that were also able to regulate system $\mathrm{L}$ transport activity in response to amino acid restriction. The system $L$ transport properties of the hybrid cell lines were similar to the regulated transport phenotype characteristic of the CHO-R100 cell line. These results suggest that CHO-R100 cells contain a dominant element that can regulate the system $L$ transport activity contributed by the two parental cell lines. The slightly higher level of leucine transport activity shown by the hybrid cell lines over that seen for CHO-R100 (e.g., Fig. 1) may result from a limitation in the amount of the regulatory element such that the hybrid cells cannot completely repress their transport activity.

Previously, we provided evidence suggesting that the enhancement of system $L$ activity in the $\mathrm{CHO}-t s \mathrm{H} 1$ cell line at elevated temperatures is regulated at the level of translation [Shotwell et al., 1982]. The constitutively elevated system $\mathrm{L}$ transport activity seen in the $\mathrm{CHO}-\mathrm{C} 11 \mathrm{~B} 6$ cell line could be the result of the loss of a regulatory element that acts as a repressor at the level of translation, possibly responding to the level of charged leucyl-tRNA. Alternatively, the regulatory factor may modify transport activity at the membrane. The latter possibility is interesting in light of the recent cloning of rabbit and rat cDNAs which, when injected into Xenopus oocytes, result in enhanced neutral and cationic amino acid uptake into the oocytes [Tate et al., 1992; Wells and Hediger, 1992; Bertran et al., 1992]. The authors concluded that the cloned component may be a regulatory element or a component of a transport complex that can activate an endogenous but inactive oocyte transport system, rather than serving as an actual transporter molecule itself, since the deduced 
amino acid sequence of the rabbit kidney cDNA suggests there is only one membrane-spanning domain [Wells and Hediger, 1992; Bertran et al., 1992]. CHO cell mRNA was recently used in an oocyte expression system and resulted in enhanced $\mathrm{Na}^{+}$-independent leucine uptake as well as increased uptake of other neutral and cationic amino acids [Su et al., 1992]. The eventual cloning of leucine transport components should help elucidate the molecular basis of system $\mathrm{L}$ transport properties.

Although temperature-sensitive synthetase mutant cell lines show increased leucine transport activity at the nonpermissive temperature, the increase in transport activity still does not allow these cells to survive at elevated temperatures, possibly because of the delay $(6-8 \mathrm{~h})$ in reaching maximum transport activity and increased intracellular leucine levels. The regulatory mutant cell lines may be temperature resistant because they are able to maintain high intracellular leucine levels. The hybrid cell lines, like the CHO-R100 cell line, are able to regulate leucine transport activity, which results in a temperature-sensitive phenotype. These results support the hypothesis that the temperature sensitivity or resistance of cells with a defective leucyl-tRNA synthetase is determined by the level of system L transport activity of the cells.

\section{ACKNOWLEDGMENTS}

We thank Dr. Ernest Chu and Ms. Barbara Lamb for their advice on cell fusion. We also thank Dr. Christopher J. Batie for the software used for the kinetic analyses. This work was supported by grant GM20737 from the National Institutes of Health to Dr. Dale Oxender.

\section{REFERENCES}

Adair GM, Thompson LH, Lindl PA (1978): Six complementation classes of conditionally lethal protein synthesis mutants of $\mathrm{CHO}$ cells selected by ${ }^{3} \mathrm{H}$-amino acid. Somat Cell Genet 4:27-44.

Bertran J, Werner A, Moore ML, Stange G, Markovich D, Biber J, Testar X, Zorzano A, Palacin M, Murer H (1992): Expression cloning of a cDNA from rabbit kidney cortex that induces a single transport system for cystine and dibasic and neutral amino acids. Proc Natl Acad Sci USA 89:5601-5605.

Collarini EJ, Oxender DL (1987): Mechanisms of transport of amino acids across membranes. Annu Rev Nutr 7:75-90.

Collarini EJ, Campbell GS, Oxender DL (1989): Isolation and characterization of Chinese hamster ovary cell mutants defective in amino acid transport system L. J Biol Chem 264:15856-15862.

El-Gewely MR, Oxender DL (1985): Gene transfer and cloning of the amino-acid transport system $\mathrm{L}$ from human cells. Ann NY Acad Sci 456:417-419.
Farber RA, Deutscher MP (1976): Physiological and biochemical properties of a temperature-sensitive leucyltRNA synthetase mutant ( $t s \mathrm{H} 1$ ) and revertant from Chinese hamster cells. Somat Cell Genet 2:509-520.

Gazzola GC, Dall'Asta V, Franchi-Gazzola R, White MF (1981): The cluster-tray method for rapid measurement of solute fluxes in adherent cultured cells. Anal Biochem 115:368-373.

Giles RE, Shimizu N, Ruddle FH (1980): Assignment of a human genetic locus to chromosome 5 which corrects the heat sensitive lesion associated with reduced leucyl-tRNA synthetase activity in $t s 025 \mathrm{C} 1$ Chinese hamster cells. Somat Cell Genet 6:667-687.

Klebe RJ, Mancuso MG (1981): Chemicals which promote cell hybridization. Somat Cell Genet 7:473-488.

Lau Y-F, Kan YW (1983): Versatile cosmid vectors for the isolation, expression, and rescue of gene sequences: Studies with the human $\alpha$-globin gene cluster. Proc Natl Acad Sci USA 80:5225-5229.

Lobaton CD, Moreno A, Oxender DL (1984): Characterization of a Chinese hamster-human hybrid cell line with increased system $\mathrm{L}$ amino acid transport activity. Mol Cell Biol 4:475-483.

Moore PA, Jayme DW, Oxender DL (1977): A role for aminoacyltRNA synthetases in the regulation of amino acid transport in mammalian cell lines. J Biol Chem 252:7427-7430.

Moreno A, Lobaton CD, Oxender DL (1985): Regulation of amino acid transport system $\mathbf{L}$ by amino acid availability in CHO-K1 cells. A special role for leucine. Biochim Biophys Acta 819:271-274.

Mulnar AJ, Rauth AM (1975): Effect of leucine on the temperature-sensitive phenotype of a mammalian leucyltRNA synthetase mutant. J Cell Physiol 85:173-178.

Mulnar AJ, Rauth AM (1979): The effect of amino acids on the temperature sensitive phenotype of the mammalian leucyl-tRNA synthetase mutant tsH1 and its revertants. J Cell Physiol 98:315-326.

Shotwell MS, Jayme DW, Kilberg MS, Oxender DL (1981): Neutral amino acid transport systems in Chinese hamster ovary cells. J Biol Chem 256:5422-5427.

Shotwell MA, Mattes PM, Jayme DW, Oxender DL (1982): Regulation of amino acid transport system $\mathrm{L}$ in Chinese hamster ovary cells. J Biol Chem 257:2974-2980.

Shotwell MA, Collarini EJ, Mansukhani A, Hampel AE, Oxender DL (1983): Isolation of Chinese hamster ovary cell mutants defective in the regulation of leucine transport. J Biol Chem 258:8183-8187.

Su T-Z, Logsdon CD, Oxender DL (1992): Chinese hamster ovary mRNA-dependent, $\mathrm{Na}^{+}$-independent L-leucine transport in Xenopus laevis oocytes. Mol Cell Biol 12:5281-5287.

Tate SS, Yan N, Undenfriend S (1992): Expression cloning of a $\mathrm{Na}^{+}$-independent neutral amino acid transporter from rat kidney. Proc Natl Acad Sci USA 89:1-5.

Thompson LH, Harkins JL, Stanners CP (1973): A mammalian cell mutant with a temperature-sensitive leucyltransfer RNA synthetase. Proc Natl Acad Sci USA 70: 3094-3098.

Wells RG, Hediger MA (1992): Cloning of a rat kidney cDNA that stimulates dibasic and neutral amino acid transport and has sequence similarity to glucosidases. Proc Natl Acad Sci USA 89:5596-5600.

Worton RG, Duff C (1979): Karyotyping. Methods Enzymol 58:322-343.

Zak B, Cohen J (1961): Automatic analysis of tissue culture proteins with stable Folin reagents. Clin Chem Acta 6:665670. 